\title{
Class talk: habitus and class in parental narratives of school choice
}

\section{Beverley Hill \& Ai-Ling Lai}

To cite this article: Beverley Hill \& Ai-Ling Lai (2016) Class talk: habitus and class in parental narratives of school choice, Journal of Marketing Management, 32:13-14, 1284-1307, DOI: 10.1080/0267257X.2016.1170719

To link to this article: http://dx.doi.org/10.1080/0267257X.2016.1170719

曲 Published online: 27 Apr 2016.

Submit your article to this journal

LIII Article views: 358

Q View related articles $₫$

View Crossmark data \lceil 


\title{
Class talk: habitus and class in parental narratives of school choice
}

\author{
Beverley Hill a and Ai-Ling Lai ${ }^{\mathrm{b}}$
}

aBristol Business School, University of the West of England, Bristol, UK; ${ }^{\text {bS }}$ chool of Management, University of Leicester, Leicester, UK

\begin{abstract}
This article explores how social class is linguistically negotiated and contested in parental narratives of school choice in the British education marketplace. Our study reveals prevalent yet obscured vestiges of 'class talk', and in doing so, unmasks 'micro-political' acts of status claiming. Using interactional narrative interviewing with 30 parents, we explore how inter- and intra-class differences are emotionally expressed, thus exposing the embodied dispositions of parents' habitus and its' subtle influence on school choice. The parental narratives also unveil a moral and political tension between the neoliberal ideal of entrepreneurial self-advancement and an egalitarian sentiment for social equality. Our study therefore challenges the neoliberal educational policy of market choice in closing the attainment gap.
\end{abstract}

\section{ARTICLE HISTORY}

Received 31 October 2014

Accepted 6 December 2015

\section{KEYWORDS}

Social class; language; habitus; Bourdieu; school choice; neoliberalism

Rich thick kids do better than poor clever children when they arrive at school [and] the situation as they go through gets worse. Schools should really be engines of social mobility to overcome the disadvantages of birth but, unfortunately, despite the best efforts of many, many people, the situation gets worse.

(Michael Gove, Secretary of State for Education 2010-2014, Evidence to Commons Education Select Committee, 27 July 2010)

\section{Introduction}

This article explores the negotiation of social class through language by analysing parental narratives of school choice in Britain. The relationship between social class and education in the UK has been a long and enduring one. Indeed, it has been said that 'the history of English education is very much a history of social class' (Ball, 2013, p. 3). So entrenched is social inequality in the schools of Britain that Michael Gove, as Education Secretary, proclaimed that there is a 'yawning gap' in education attainment (Shepherd, 2010), which successive government policies have been unable to close. More importantly (and emotive language aside), Gove's remark points to the lingering presence of class prejudice, where one's life chances continue to be patterned in 
accordance to one's class position, so that 'thick kids' from affluent backgrounds are afforded 'better' chances of success than 'clever poor kids'.

While Gove stresses the importance of schools in engineering social mobility, Atkinson (2010) questions whether the impetus to climb the social class ladder can be accomplished through reflexivity - i.e. 'the ability to actively think and choose how to live, what to value and what to become' (p. 2). While Atkinson acknowledges that reflexivity can be cultivated through the education system, he maintains that the aptitude for reflexivity is in itself a skilled-disposition, instinctive to those who possess ample stocks of cultural and economic capitals. As such, he argues against the thesis of reflexivity stating that while we have witnessed erosion in the overt 'symbolic' differences of class, $^{2}$ this does not signal the demise of class itself. Samuel (1959) concurs, claiming that inter-class movement engendered by educational/occupational opportunities merely reinforces social stratification in a way that is accommodating to the upwardly mobile without necessarily displacing traditional class structure. This point is well illustrated in Rivera's (2015) study of the US labour market in which she demonstrates how elite reproduction continues beyond schooling and higher education through the class-biased recruitment practices of prestigious employers.

With the erosion of overt class differences, Kravets and Sandikci (2014) argue that class practices have become more subtle, and thus, necessitate an analysis that reveals the tacit operations of social stratification. Reay (2005, p. 914) contends that the UK educational system constitutes 'a social context where the workings of class are not only concentrated and made explicit but are also heavily implicit'. Despite political claims to classlessness (Lawler, 2005b), class and moreover the emotional, subjective experience of class referred to as 'class consciousness' (Reay, 2005), continues to infiltrate our choices and actions.

In consumer research, Henry and Caldwell (2008) observe a 'hiatus' in the study of social class, suggesting that this is in part attributed to the 'myth of social equality'. Such a myth fosters a widespread, if mistaken belief in 'classlessness' (Hall, 1958), which has subsequently rendered 'class' redundant as a unit of analysis. In an attempt to revive the interest of consumer researchers, Holt $(1998$, p. 1) dispels the myth of classlessness, arguing that consumption patterns remain inextricably consequential to the reproduction of social distinction. Holt (1998) and Henry and Caldwell (2008) therefore propose a reinvigoration of class study through the writings of Bourdieu to understand the socio-historical patterning of class distinction and how this is manifested in consumption activities. Our article follows this tradition, drawing on Bourdieu to further the understanding of class as a habituated disposition, in which individuals (parents) orient their practices (school selection) 'either toward the preservation of the distribution of capital or toward the subversion of this distribution' (Bourdieu \& Wacquant, 1992, p. 108).

Consumer researchers have variously employed Bourdieu's theory of cultural capital (Callaghan \& Wistow, 2006; Coskuner-Balli \& Thompson, 2013; Henry, 2005; Johnston \& Baumann, 2007; Rademacher, 2008; Üstüner \& Holt, 2010) and taste (Allen, 2002; Arsel \& Bean, 2013; Holt, 1998; Johnston, Szabo, \& Rodney, 2011), which resonate with the research agenda of Consumer Culture Theory (Arnould \& Thompson, 2005) to investigate 'the socio-cultural processes by which consumption choices, tastes, preferences, lifestyle patterns and behaviours are systematically structured by social 
class hierarchies' (p. 84). While these studies have contributed to a nuanced understanding of inter-class differences, Kravets and Sandikci (2014) argue that the 'taste dynamics' within one class faction - in particular that of the 'middle class' remain under-theorised. Our article addresses this gap by exploring how intra-class dynamics reinforce social hierarchies among the middle classes. This reflects Bourdieu's relational view of class - in which one's social position is defined relative to another (Atkinson, 2010).

In addition, our article aims to explore previously overlooked aspects of language and class. We argue that such an oversight is predicated on the assumption that habitus operates on a pre-reflexive level and thus is enacted prior to the discursive objectification of class (Atkinson, 2010). Yet, as Holt (1998) observes, social interactions (talk) are 'micro-political acts of status claiming' (p. 4) and as such constitute embodied dispositions (Argaman, 2009) that equip individuals with linguistic resources to negotiate their reputational positions. According to Atkinson (2010), 'class talk' emerges as a discursive site where the struggle over symbolic legitimation and class power are played out. Through 'class talk' then, individuals are able to make sense of their place in the world and to establish their social differences relative to others. In short, 'class talk' is an embodied as well as a discursive practice that enables the articulation of class while perpetuating the classification struggle in the jockeying for social position.

This article commences with a critical review of parental choice as a neoliberal educational policy and how this leads to the construction of parents-as-consumers. Using Bourdieu's concept of the 'habitus', we consider how the privileging of consumer choice has reinforced class distinctions within the education marketplace. We then discuss the narrative approach that underpins the methodology of this study before presenting our analysis of 'class talk', which emerged as participants justified their school preferences from the vantage point of their class positions.

\section{Parents-as-consumers: parental choice as a neoliberal education policy}

In October 2005, the UK Government under the Labour Party published the White Paper 'Higher Standards, Better School for All' highlighting the need for educational reform centred on increasing parental choice. Such reform was imperative to the government strategy to democratise the educational experience (Weekes-Bernard, 2007). According to Ball (2003), the privileging of choice transforms education in Britain into an individualised marketplace where parents are free to choose which school their children attend. ${ }^{3}$ It is within this political discourse of market choice that the category of parents-as-consumers comes into being and where, according to political rhetoric, parents are 'empowered' through their sovereignty as consumers of education (Byrne, 2009).

With this, a new form of neoliberal market citizenship is created, revolutionising conceptions of democracy and civic commitments (Ball, 2007). According to Harvey (2005), neoliberalism is predicated on the emancipation of individual's entrepreneurial capacity while minimising state intervention to optimise free market exchange. Deregulation, privatisation, fair competition and consumer choice are thus hallmarks of neoliberal public policies, where the withdrawal of the state from welfare/social 
provision (such as education) is said to be crucial in eliminating bureaucracy. Free market, according to neoliberal rhetoric, should lead to an increase in productivity and efficiency, and thus, reduce cost and lighten the taxpayer's burden (Harvey, 2005).

Concurrently, the market system is underpinned by an ethical framework that binds individuals into contractual relations (Harvey, 2005), thereby shifting state obligations into the hands of individuals. Market citizen is therefore 'compelled' by the discourse of personal responsibility (Rose, 1992) to partake in market competition (Reay, 2008) in order to advance one's position (Ball, 2003). In a neoliberal education marketplace then, parents-as-consumers must actively participate in the schooling of their children by exercising informed choices in a self-enterprising manner (Bauman, 1997; Perry \& Francis, 2010). Ball (2003) argues that the middle class conception of responsible choice involves seeking maximal positional advantage for their children and family i.e. putting one's family first.

Reay et al. (2008) suggest that the pursuit of competitive familial advantage (Oría et al., 2007) is intensified in an era of what Savage (2000, p. 139) calls the 'individualising of middle class career'. This is an era of anxiety as middle class parents are increasingly concerned about the future career of their offspring (Ball, 2003). ${ }^{4}$ In response, middle class parents defend their status quo by tapping into their market knowledge to gain competitive advantage for their children and so, enable them to stay ahead of the race (Ball, 2007; Reay, 2008). Education is therefore seen as a long-term 'investment' by middle class parents (Allen, 2002; Archer, Hollingworth, \& Halsall, 2007) to endow their children with an advantageous 'head start' (Bourdieu, 1986). Subtextually however, the liberation of parental choice means that the onus is on parents to act in the interest of their children, thus eliminating what Ball (2007) calls the 'dependency culture'.

Hence, individuals who fail to exercise choice and to advance one's self in an entrepreneurial manner are deemed 'irresponsible' and thus come to be portrayed as 'flawed consumers' (Bauman, 1997; Hayward \& Yar, 2006). As such, Reay and Ball (1997) suggest that education choice is modelled on a middle class norm that engenders a culture of blame which pathologises working class families as 'bad choosers', 'bad parents', 'inadequate' and 'a liability'. In her research on parental choice in the American school system, Johnson (2015, p. 31) observes the 'hidden injury' sustained by families who lack economic and cultural capitals as they struggle with internal conflicts (for their inability to afford the best education for their children) as well as symbolic violence directed at them by those who are privileged.

According to Johnson (2015), the US education system is inextricably bound by the American Dream, which upholds the belief in meritocracy. Education is assumed to be a great equaliser that enables individuals to achieve upward mobility regardless of their social background. Her research however reveals the fallacy of meritocracy, which serves as an ideological smokescreen that furthers the interest of those who can harness the power of wealth to secure a promising education for their children. Citing Brown (2000), Ball (2003) argues that a neoliberal restructuring of education has shifted the rule of exclusion - i.e. the measures by which individuals or groups of individuals are systematically excluded - from meritocratic rules to market rules. Meritocratic rules assume that all parents have access to the same information and that they are equally capable of making informed choices (Alexander, 2007; Harvey, 2005). This presumes that individuals are competing on a level playing field (Harvey, 2005; Johnson, 2015). 
With the shift towards the market rules of exclusion, Ball (2003) argues that only those who are capable of mobilising purchasing power can successfully 'play the game' in a competitive education marketplace (Johnson, 2015). This led many scholars to suggest that UK government policy is based on a consumerist vision that is embraced primarily by the middle classes (Gewirtz, Ball, \& Bowe, 1992). According to Ball (2003), the language of 'choice' that permeates UK educational policy is distorting since it obscures the discriminative workings of the market and this according to Bourdieu (1986) conceals the complicity of individuals in the collective act of perpetuating social inequalities (Heath, 2009; Reay et al., 2008). Tyler (2008) sees this as a form of unspoken class antagonism which works to subordinate working class parents as a means of reinforcing middle class identities (Lawler, 2005a). Citing Polanyi (1944), Harvey (2005) contends that the idea of freedom (free choice) has been corrupted by neoliberalism in the interest of free enterprise. As such, Harvey is disenchanted by the promise of a neoliberal free market, claiming that it is a 'failed utopian rhetoric masking a successful project for the restoration of ruling class power' (p. 203). As such, education is a field where contestations of class distinction are played out and where the rules of exclusion are strategically invested through market power to ensure inter-generational transmission of economic, social and cultural capitals (Bourdieu, 1986; Byrne, 2009). Yet, the ability to deploy class capitals is predicated on the situatedness that conditions one's habitus (Henry \& Caldwell, 2008), as we discuss below.

\section{Habitus: an embodied disposition of parental choice}

Bourdieu's work illuminates the workings of habitus and how, as a system of embodied dispositions, it equips middle class parents with an exclusionary stance. Bourdieu (1977) describes habitus as a socialised body, in that it constitutes sedimentations of social structure, history and personal experience (Allen, 2002; Reay, 2004a). In this way, Bourdieu argues against the inscription perspective, which posits that the social world (external structure) 'imposes itself onto' the passive body. Rather the 'social is in the body' (Reay, 2004a, p. 432), which actively predisposes one's ways of thinking, feeling, being and acting (Holt, 1998; Reay, 2004a). Bourdieu's discussions of instinctive 'feel for the game' and embodied competences have particular relevance for school choice.

\section{A feel for the game: visceral and expressive order of choice}

First, in its interaction with the world, the body-as-habitus becomes instinctively sensitised to gain a feel for the game (Bourdieu, 1990), often experienced as an 'embodied knowing' - i.e. a visceral gut feeling of fitting-in and feeling right (Gewirtz et al., 1992; Henry \& Caldwell, 2008). Depending on one's social position, the body-ashabitus inculcates a structure of dispositions, which are acculturated through past and present experiences of class. Thus our habitus shapes perceptions of what is un/familiar, un/natural, un/acceptable, un/comfortable and tasteful/vulgar (Archer et al., 2007).

According to Byrne (2009), education is as much about the acquisition of 'appropriate tastes' as it is about the inculcation of 'right' dispositions. Ball (2003) found that middle class parents exercise school choice based on an expressive order (gut feeling), whereby parents seek schools attended by students who embody 
demeanours and lifestyles that mirror their class taste (Bagley, Woods, \& Glatter, 2001; Johnson, 2015). As Bourdieu (1986) argues, taste is not only a manifestation of one's class position but it also produces social judgement that distances us from them. The Sutton Trust claims that parents tend to choose certain types of school to ensure their children are educated with people like us (Ball, 2003; Byrne, 2009; Frean, 2008). It is therefore unsurprising that the middle class parents interviewed by Ball (2003) express fear and ambivalence in allowing their children to 'mix' with the working class 'other'. Ball (2003, p. 62) describes this aversion as 'a grating of habituses, a sense of being uncomfortable, of being in the wrong place and the social space of the school as contaminating'.

\section{Embodied competence: like a fish in water}

Second, Bourdieu (1990) argues that our body-as-habitus invokes a sense of competence (i.e. ability to play the game), in which individuals are afforded certain 'possibilities and impossibilities, freedom and necessities, opportunities and prohibitions' (Bourdieu, 1990, p. 54). So, depending on one's social position in the field, our habitus opens up a repertoire of choices while also closing off another. Bourdieu envisions the body as equipped with an embodied 'know-how' that enables one to navigate the social world in a pre-reflexive and taken-for-granted manner (Atkinson, 2010).

According to Archer et al. (2007), the lifeworld of the middle classes are said to be synergistically co-ordinated with dominant social institutions and structures, which familiarise them to the 'rules of the game'. Reay and Ball (1997) speak of the middle classes as 'being at home' in education. Like 'fish in the water' (Bourdieu, 1990), they are able to flow seamlessly within the education system and exert control over their schooling experiences. On the contrary, the working class experience of education is often described as 'out-of-place' (Allen, 2002; Reay \& Ball, 1997), highlighting their sense of alienation and disjuncture (Archer et al., 2007). Consequently, Byrne (2009) argues that middle class parents display greater confidence in negotiating possibilities of choice for their children than parents from a working class background.

In sum, Bourdieu's theory refutes the conceptualisation of choice as a rational and instrumental practice. Rather, choices are enacted through one's 'practical' and 'instinctive' engagement with the world which incorporates an emotional and subjective dimension. Therefore Rafferty (2011) argues that there remains a gap in research to conceptualise consumer agency as unfolding within social class structures that are underpinned by the sentient/emotive body.

This article aims (1) to uncover the undercurrent of 'class talk' in our data by drawing on Bourdieu's concept of the habitus to demonstrate how social class - as an embodied system of practical disposition - is enacted to drive school choice. In so doing, our research seeks (2) to reveal inter- and intra-class dynamics that shape middle class habitus as parents construct their social position in relation to each other. Lastly, we (3) explore the extent to which middle class parents are able and/or willing to transcend their habituated dispositions as they contemplate their choice of schools. In the next section, we outline and reflect on how our choice of method reveals the emotional expression and subtleties of class within the British education marketplace. 


\section{Methodology}

Through narrative interviewing (Mishler, 1986), this study focused on parents' experiences of choosing schools in the South West of England, UK. As the grapevine influences school selection (Ball, 2003), snowball sampling was utilised to identify parents who had recently chosen a primary school for a child. ${ }^{5}$ We selected parents who had visited more than one school, without stipulating type of school (fee-paying/ state school). This enabled us to capture a diversity of educational establishments, which reflect a multi-layered gradation of class hierarchy imagined by parents. The sampling process yielded 30 participants, and the referral process terminated when data saturation was reached.

Geographically, the South West of England provides an alternative to the many innercity (Atkinson, 2010; Reay, 2004b) and London-based studies (e.g. Ball, 2003) of school choice. The region has 2,573 schools, 232 of which are independent fee-paying schools (Gov.UK, 2014), with termly fees in excess of the national average (ISC census, 2013). Only $13.3 \%$ of pupils in the region's state funded nursery and primary schools are eligible for and claiming free school meals, compared with $21 \%$ in London and $17 \%$ in England (Gov.UK, 2014). The eligibility of free school meals has been used by the Deputy Prime Minister's Office (2015) as a class indicator, whereby those who are entitled are deemed to be from 'poor' families (Reay, 2006). This suggests that the majority of pupils (86.7\%) from the South West belong to the 'middle' strata of society. Census data also indicates that $95 \%$ of the South West population declared their ethnicity as 'white' (ONS, 2011). Our sample reflects these demographics, in that all our participants are white and can be considered relatively affluent; none were eligible to claim free school meals and many were located in the middle and higher categories of Savage et al.' s (2013) model of social class. ${ }^{6}$ Moreover, many (43\%) were able to consider fee-paying schools. For a profile of participants, see Appendix A.

Our sample's lack of racial and class diversity can be largely attributed to the geographical context of the research and the referral sampling procedure rather than an unquestioning assumption of a white middle class norm (Byrne, 2009). The sample is unrepresentative of the UK population, yet its homogeneity enables an in-depth exploration of the dynamics and internal divisions (Archer, 2011) of a group of parents that Kravets and Sandikci (2014) describe as being comfortably 'in the middle'.

All our participants were mothers, 29 of whom were married. Fathers did not emerge in the sampling procedure, reflecting David et al.'s (1994) study that mothers predominate in choosing primary schools. Our data reveal that fathers were involved in the decision-making process, but it was most often mothers who visited these schools. This is not surprising, as according to Reay (2004c), mothers are bearers of emotional capital, who devote their time and skills to manage and advance their children's education.

This study employed an interactional form of narrative interviewing (Mishler, 1986; Riessman, 2004), which involves a collaborative telling of stories between the interviewer (first author) and the participants. The interview therefore constitutes a dialogical space where personal stories, organised around the participants' individual and affective experience of school choice are articulated. Prompted by an initial request to describe the experience of visiting and choosing schools, the interviews elicited 
narratives replete with detailed anecdotes of their 'upbringing', 'schooling background' and 'peered experience' as well as subjective emotions, which can only be enabled through qualitative methods (Atkinson, 2010). Narratives encourage speakers to retrospectively construct their biography, through which they choose which accounts to tell and how to tell them. As such, narratives incite revelations that often unintentionally convey 'tacit and unconscious assumptions and norms of the individual or of a cultural group' (Wengraf, 2001, p. 115). To enable the spontaneous telling of stories, the interviews took place at the homes of participants.

Participants were not asked to self-identify their class position or to label that of others. Instead, we explored how participants themselves used 'class', perceptually and linguistically (Atkinson, 2010, p. 161) to account for their school choice. This allows for the emergence of 'class talk' as participants attempt to make sense of their decisions and how they implicitly position themselves and others within the classed hierarchy (Atkinson, 2010; Perrier, 2012). It is in such accounts that class experiences are revealed (Savage, 2000) as participants offer observations and evaluations of the social environment of the school from the interpretive standpoint of their class positions.

In analysing the narratives, we were alerted to explicit social class terminology and more implicit 'class talk', recognising that class evaluations can imply moral judgements (Reay, 2005; Sayer, 2002), which participants may choose to mitigate through linguistic means. We detected a number of face-saving (e.g. confession, normalisation) and linguistic strategies (e.g. categorisation, symbolic violence, comparison) employed by participants to craft a socially acceptable account of class differentiation. We paid close attention to these strategies in our analysis as language can reveal underlying assumptions of class which are often unspoken in a society where class is linguistically expunged (Lawler, 2005b; Young, 2014). In particular, we bring to light the emotional articulation of class and how this reflects broader socio-cultural understanding and political ideologies pertaining to education and class. As such, our data interpretation follows a dialectical process (Thompson \& Haytko, 1997), where personal experiences derived from the interview text are scrutinised for patterns of 'class talk' and how they are expressed in relation to the wider macro-political framework.

As the principal interviewer, the first author undertook the preliminary interpretation of the interview texts by incorporating nuances and non-verbal cues observed during her personal encounter with the participants. This was then shared with the second author, who jointly performed a fine-grained linguistic analysis of the data. As a nonBritish, the second author flagged up specific cultural idiosyncrasies pertaining to the British class system, classed expressions as well as the UK education system that are unfamiliar to her. This heightens the reflexivity of the first author, who as a native, called into question the tacit cultural understanding of class in Britain. In this way, the first author and the second author constitute what Fish (1980) calls an interpretive community - i.e. a community 'made up of those who share interpretive strategies' (1980, p. 14).

Lastly, our participants were informed of the purpose of this study and were reassured of their rights to voluntary participation. They have all signed a consent form stipulating their agreement to be audiotaped. In order to protect privacy, we use pseudonyms to refer to our participants and schools. In the extracts below, we remove 
personally identifying information but we noted the choice of school (state or feepaying) following each participant's pseudonym.

\section{Analysis}

Iterative readings of parental narratives identified three intricately interwoven and overlapping patterns of 'class talk'. First, our participants' narratives reveal bidirectional class contempt (Lawler, 2005b) as they attempt to establish social differences by 'distancing' themselves from those 'above' and 'below' them (Atkinson, 2010; Sayer, 2002). Second, our participants express a sense of (un)familiarity of (not) fitting in with 'people like us' (Byrne, 2009) and thus, proclaim that their school choice reflects the desire for being comfortable 'in the middle' (Kravets \& Sandikci, 2014). Finally, our participants' narratives uncover an undercurrent of middle class guilt, which exposes the moral dilemma of being a good parent and being an egalitarian citizen.

\section{Establishing social distance: class contempt}

We commence with a narrative from Lydia, whose narrative exposes the enduring presence of class distinction in British society, its relational nature (Atkinson, 2010) and more specifically the subtle social distance that reinforces an intra-middle class hierarchy. This is reflected in her comparison of Beechtops (a prestigious fee-paying school) and Ringlaston (a less prestigious fee-paying school).

There are the social nuances as well...(At Beechtops) a lovely man talked to us and showed us round, Deputy Head I think, but tweed jacketed you know, the 'old school', charming and delightful but um altogether of a different sort of world....Well, it's very sort of grand looking, a big manor, not for us...very more sort of public school...(It's) quite fascinating the social structuring that goes on in the country isn't it, you know you've got the posh hunting, I mean we have got hunting ones at Ringlaston as well but they are much sort of grander somehow at Beechtops...somebody said to me,...they said oh well the lords and ladies send their children to Beechtops and the farmers send them to Ringlaston and that's how it used to be...Absolutely, that's how it was, and the social distinctions are that defined. (Lydia, fee-paying school)

Lydia observes how class hierarchy is reproduced in both schools, which set apart the elite from the non-elite (Lucey \& Reay, 2002). Without prompting, Lydia uses the term social structuring and is alerted to the fine-grained internal divisions (Archer, 2011) that pervade the wealthier strata of the middle classes. She illustrates this with reference to hunting. Hunting, implied as an elite pastime, is considered a classed practice (Huggins, 2008), as it involves an embodied 'know-how' that the upper classes have historically mastered. Lydia's observation of hunting being much grander at Beechtops than Ringlaston points to a gradation of middle class distinctions. Using typification as a linguistic device (Atkinson, 2010), Lydia describes Beechtops as being more elitist (posh) since it is historically attended by children of the aristocrats (lords and ladies) while Ringlaston typically attracts children of the land owners (farmers).

Lydia's visit to Beechtops evokes in her a feeling of alienation, which exacerbates her sense of class incompetence. This prompts an 'embodied knowing' that this school is not 
for us. Notably, the old school charm of the Deputy Head belongs to a different sort of world to hers, conjuring an image reminiscent of British public school grandeur. For Lydia, the stereotypes of elitism are encapsulated through class markers such as grand manor houses and tweed jackets. Elitist markers such as huge houses, big farms are also observed by Patricia, below, who rules out Beechtops on class grounds.

I mean it is probably one of the reasons why we didn't even look at Beechtops because that tends to have them more seriously...wealthy you know, huge houses, big farms um...and we just felt that, that we're not from that sort of background and. . at Whitely I think we felt there was more...people that were, were working in order to afford to send their children to quite a....a more down to earth um...working parents. (Patricia, fee-paying school)

Here, Patricia distinguishes parents at Beechtops whom she describes as seriously wealthy from parents at Whitely whom she regards as more down to earth. For Patricia, the term down to earth reflects Weber's Protestant Work Ethic (Weber, 1905), which equates hard work with virtue, suggesting an implicit criticism of the taken-forgranted affluence enjoyed by the seriously wealthy. In doing so, she claims solidarity with the working (middle class) parents who like herself, have to strive towards building sufficient economic resources to fund private education. As such, Patricia discounts Beechtops since she is not from that sort of background, signifying a clashing of habituses (Ball, 2003). Like Lydia, Patricia's narrative illustrates intra-class differences that exist within the upper echelons of society. While Lydia and Patricia ultimately choose less elitist fee-paying schools, Rachel rejects fee-paying schools altogether despite having the means to afford private education.

The one thing that....certainly puts me off is if we went into the private sector I wouldn't want to feel that my children were worse off than anybody else... and I think....in that sort of environment I felt that there was competitiveness amongst the parents... which I don't necessarily like...Seeing some individuals who have been privately educated...they're not nice individuals because of it, they seem to think they are far more superior... some of the parents are normal (like her) and then you've got some incredibly wealthy (parents). I know friends who were privately educated and always felt that they were the paupers in the situation... and you think well I would hate for my child to feel that (Rachel, state school).

Like Patricia, Rachel denigrates the privately educated whom she associates with the possession of immense wealth. Here we witness bi-directional symbolic violence (Sayer, 2002) where Rachel sustains the perceived 'hidden injury' (Johnson, 2015) of being made to feel inferior by those 'above' her (they are far more superior) while at the same time adopting an offensive strategy by disparaging the privately educated as not nice. Here, Rachel employs normalisation (Atkinson, 2010) as a discursive strategy to categorise the parents at private schools into those who are normal like herself and those who are incredibly wealthy - and by implication not normal. Rachel expresses her discomfort at the thought of having to keep up with the incredibly wealthy parents, who possess a financial cushion that enables them to engage in a competitive game of jockeying for social status. To substantiate her claim, Rachel draws on the experience of her privately educated friends (who are not incredibly wealthy), who recount feeling like paupers at fee-paying schools - a situation which she wants to avoid for her children. In a similar vein, Francesca's narrative also reveals symbolic violence, this time directed 'downward' at the parvenus (Bourdieu, 1984). 
...because we'd heard some very off-putting bits about the school, like the car park which is full of the most vulgar four wheeled drive cars and my mother came up and said 'Darling you just can't send them here, why just look at the cars, they must be such vulgar people (laughing). (Francesca, fee-paying school)

Francesca, who comes from a family of established wealth, is aghast by the four wheeled drive cars she encounters at a fee-paying school. For her, the four wheel drive is a signifier of the nouveau riche (Veblen, 1899), who attempt to emulate those from the upper strata of society. She considers such conspicuous consumption as off-putting, an excessive display of wealth (Hayward \& Yar, 2006). This reflects Holt's (1998) comment that materialism is considered vulgar and those whose tastes are formed by economic capital are disavowed. Adopting this exclusionary tactic, 'cultural elites' such as Francesca 'invert materialism to affirm their social position' (Holt, 1998, p. 248). The ostentatious lifestyle of the nouveau riche therefore evokes a 'grating of habituses' (Ball, 2003) for Francesca as she recognises that the parents at the school are not 'people like her', a theme which we explore below.

\title{
(Un)familiarity of (not) fitting in with 'people like us': being comfortable in the middle
}

The narratives presented so far demonstrate how parental choice is orientated towards blending in with 'people like us' (Byrne, 2009). This resonates with Kravets and Sandikci's (2014, p. 126) argument that the 'middle' constitutes an 'imagined site of normality and comfort' as portrayed in Emma's narrative below:

\begin{abstract}
Beechtops, which...we found in the Good Schools Guide....my husband knew about Beechtops...he'd heard about it again probably word of mouth..........but we'd heard that it was a fairly traditional school, a country side school and we liked the thought of that... and the setting was really important....absolutely stunningly beautiful, on the side of the hill and right next to the common.....and the idea that when it snows the children go out on the common and make snowmen....we had a strong idea about what we wanted for Charlotte....we quite like the idea of....tradition and um...we like the idea of a....an education of all the traditional things associated with education um....which...is a good balance between the arts and the sciences and good facilities....um....discipline um...the development of the whole child.....and we felt that that was really lacking now in the state system...We met the Head teacher and his wife and that was quite formal I suppose.. we chatted about art really and just said about what we wanted and they were very, very accommodating which I think when you're paying is another issue, you know you do tend to be looked after well and made to feel...comfortable about what you want. (Emma, feepaying school)
\end{abstract}

In this narrative, Emma (also speaking on behalf of her husband) expresses a strong desire for her daughter (Charlotte) to have a traditional education, which she considers is fundamental to the holistic development of a child. Emma (a teacher herself) feels at home (Reay \& Ball, 1997) with a 'conventional' curriculum, which constitutes a wellbalanced programme in the arts and the sciences. Through access to cold (Good School Guide) and hot information (word-of-mouth), Emma becomes familiarised to the 'rules of the market' (Reay \& Ball, 1997) that lead her towards Beechtops, which she describes as a fairly traditional school. This impression was further enhanced by meeting the Head Teacher and his wife, who display their cultural capital through their discussion of art. 
While Emma was made to feel comfortable and well looked after, she also questions whether her purchasing power has engendered such zealous accommodation of her demands. Assured of a balanced curriculum, Emma is also enthralled by the facilities and setting of the school, which ignite her imagination of an idyllic childhood (making snowmen) she and her husband wish to secure for their daughter. Like Emma, Penny also expresses a desire for her child to have a good old fashioned education.

I liked the fact the dining area you know and they all have to go down and sit down and you know she said they make sure they all have proper manners and......ask to leave the table and all things like that, so that was nice, good old fashioned way of thinking.... Well I just had this; I think, most probably brainwashed, private education in my mind, that's all I'm considering....That was because of my, because of my upbringing I think. (Penny, feepaying school)

On her visit to a fee-paying school, Penny gains an 'instinctive' sense (Archer et al., 2007) of familiarity that reverberates with her privately educated upbringing. This embodied instinct is referred to by Penny as being brainwashed and hence predisposes her commitment to private education. This is most notable in her observation of the dining etiquette at the school, which she associates with nice, good old fashioned values. The school dining room thus presents a social space in which cultural competence is performed, where the pupils embody proper manners (Bagley et al., 2001) that demonstrate a 'legitimate' social etiquette (Bourdieu, 1984) sought by the middle classes. Like Penny, Rebecca considers the display of appropriate manners as fundamental to her choice of school.

One of the biggest things is the catchment area, the type of child you've got in there. But I wanted my children to be with children who behave themselves, who have come from nice backgrounds, who haven't got parents who are drinking or taking drugs so they know how to behave themselves basically. I mean some of the secondary schools in [...] the children there do not know how to behave in the simplest form, swearing...l just don't want my children to be with children like that. I've been in lessons where you have you know twenty five well behaved nice children and have it absolutely ruined by five or four terribly behaved children and these are the people who usually have come from bad backgrounds, and snobby as it may seem. (Rebecca, state school)

Rebecca articulates her fear of allowing her children to mix with the 'undesirable other,' who potentially threaten to compromise the middle class mannerisms and imagined future of her own children (Ball, 2003). Rebecca's narrative is illustrative of an inter-class demarcation, as she delineates well-behaved children from nice backgrounds and terriblybehaved children from bad backgrounds. Taking a confessional stance, Rebecca acknowledges her snobbishness, yet continues to assert symbolic violence (Atkinson, 2010) against children she perceives to be from 'unacceptable' households. Rebecca is particularly contemptuous of parents who display impoverished cultural capital (Bourdieu, 1984), as manifested through excessive consumption of alcohol and drugs. Indeed her tone expresses disgust (Tyler, 2008), suggesting that she sees these families as morally reprehensible. These families are disparaged not for 'being poor' but for irresponsibly spending their money (Lawler, 2005b), exemplifying what Bauman (1997) termed 'flawed consumers'. While Rebecca expresses concern over the 'contamination of habituses' (Ball, 2003), Brigit is uncomfortable with the thought of her child being educated with those who excessively flaunt their cultural and economic wealth. 
And I suppose one of the big concerns of sending your child to somewhere like Ringlaston is you look at the stuff on the walls what they've done in the summer holidays and you think, oh my god, is my child ever going to be able to write (laugh) that they've been to sort of 3 different Caribbean islands... and sort of sit on the yacht between the lot of them and its, you know its very, you don't want your child to feel... like a fish out of water but on the other hand you don't want them to.....suffer as the result of the fact that you haven't because... your child's education is the most important. (Brigit, fee-paying school)

At Ringlaston, Brigit feels estranged by the symbolic markers of class displayed in the exhibition of students' work - i.e. essays describing holidays in the Caribbean islands and yachting. These markers provide a clue to the children's cultural competencies while signposting the cultural and economic capitals of their parents. Through an instinctive 'feel for the game', Brigit is apprehensive that her child may feel excluded from his/her more privileged peers akin to a fish out of water (Bourdieu, 1990). This reflects Bourdieu's (1986, p. 56) observation that 'taste classifies, and it classifies the classifiers'. Brigit's sense of being 'out of place' also resonates with Louise's narrative below.

Well maybe it's the class thing... I went to a comprehensive, but um the Kibrook School... when I rang ... they were wanting to know ...their expressions were not ones that I was necessarily used to, you know the 'pre prep' all the 'preps' and I think well I don't know what the difference is, you know.... (It's a) mystifying thing. Partly I suppose not so that you feel stupid but you, partly you think oh I don't know about public schools, they're above me..... Partly, you know, I mean I come from a working class background so part of me doesn't want to send my child to public school. (Louise, fee-paying school)

Louise's narrative illustrates her feeling of not being-at-home with private education (Reay \& Ball, 1997) as it jars with her working class background and her experience of attending comprehensive (state) schools. Despite having achieved upward economic mobility (through marriage), Louise struggles with her lack of cultural competencies, possessed by parents at fee-paying schools (Bourdieu, 1986). This is most notable in her telephone correspondence with Kibrook (a fee-paying school) in which her unfamiliarity with the 'rules of the game' (Archer et al., 2007) are painfully highlighted. Louise grapples with her lack of fluency in the symbolic use of private school expressions and this reflects her lack of embodied know-how in navigating the admission process at fee-paying schools (preparatory programme ${ }^{7}$ ). For Louise, the use of 'exclusionary' language (prep) constitutes a form of class antagonism (Tyler, 2008) as she is made to feel stupid and inferior (they're above me), thereby widening the inter-class chasm between us and them. As such, Louise's experience of the private education system is marked by disjuncture (Allen, 2002), which she describes as mystifying. Unlike most narratives in this study, Louise's explicit mention of class points to her reflexivity in terms of 'class consciousness' (Atkinson, 2010; Reay, 2005). Ironically, despite feeling 'out of place', Louise went against her 'working class' background by opting into private education to ensure her child is equipped with an advantageous head start (Bourdieu, 1986). Such a decision is underpinned by the moral dilemma between securing a positional advantage for her child and maintaining her class beliefs and solidarity, as we discuss below. 


\section{Middle class guilt: the moral dilemma of 'being a good parent' and 'being an egalitarian citizen'}

Our parental narratives reveal an underlying political tension between the elitism and exclusivity of fee-paying schools versus the egalitarianism and diversity that characterise state schools. The ideology of classlessness (Hall, 1958) is contested in school choice, reflecting Harvey's (2005) assertion that the disillusionment with neoliberalism as a futile ideology has paved the way towards the expression of egalitarian sentiment (Reay et al., 2008), as reflected in Emma's narrative below.

It always comes down to that statement that people say, you know that they believe in state education and then at the end of the day they send their children to private school, which I'd always sort of....told people off about you know and said how can you do that, you know. (Fee-paying schools have)...lots of green playing fields....um....good sports facilities....indoor pool, outdoor pool, I mean it just seems ridiculous when you say it out loud, it seems so unfair, really and it goes against...all our principles really I suppose, that was the hardest thing for us because we strongly believe that this sort of thing should be available for all children and um.... guess you know that was really difficult, coming to terms with that kind of privilege... And that we felt we wanted to make sure that she had a good opportunity if she did want to go to university later on or whatever, so that probably tilted it, the scales in their favour. (Emma, fee-paying school)

Emma expresses a sense of guilt over sending her child to an elite fee-paying school, despite this going against all their principles. As a state school teacher herself, Emma strongly believes in the virtue of state education, which she perceives to espouse democracy in terms of educational access (Reay et al., 2008). She is therefore appalled by the hypocrisy of parents who turn their back on state education despite expressing their belief in the sector. She ridicules the excess of facilities (indoor/outdoor pool and playing fields) offered by fee-paying schools, which are denied to students attending state schools. Despite what she deems to be an unfair privilege, Emma went against her 'gut feeling' by sending her child to an elite school, a choice which she struggles to come to terms with. Emma justifies her contradictory decision, stressing that private education potentially equips her child with an advantageous 'head start' (Bourdieu, 1986) and thus, constitutes an investment (Archer et al., 2007) in the imagined future of her child (university). While Emma was able to assuage her conscience for going against her political beliefs other parents, such as Stephanie, express a sense of regret.

...she (the Headmistress) was so 'jolly hockey-sticks', I just thought, what am I doing sending my child to this school, I'm sure I'm going to regret this (laughs), and I just, I felt so totally out of place, the whole, the whole school is so against everything that I stand for... (Stephanie, fee-paying school)

Like Emma, Stephanie decided to send her child to a fee-paying school to fulfil her duty as a good parent. However, unlike Emma, Stephanie was unable to reconcile with her decision (regret this) as the school she has chosen is against everything she stands for. Akin to a fish out of water (Bourdieu, 1990), Stephanie admits to feeling out of place (Ball, 2003). This feeling of disjuncture is made evident through her meeting with the Headmistress whom she describes as jolly hockey-sticks, a cultural representation which mocks the boisterous enthusiasm of an upper-class English public schoolgirl. The Headmistress' mannerism exudes the staunchness of English elite that is at odds 
with her egalitarian values. Like Emma and Stephanie, Francesca goes against her political beliefs by sending her child to a fee-paying school, which results in a loss of friendship.

...it was incredibly difficult because we'd made very good friends, um, with a lot of other parents at the school, in particular bosom friends with a doctor and his wife who are very, very committed socialists and as good as said 'well if you do it, you know, that's the end of our friendship almost,... but you know it's never been quite the same again... (Francesca, fee-paying school)

Francesca's decision to reject state schools has ignited a feeling of betrayal among her bosom friends whom she describes as extremely committed socialists. Francesca confesses that this decision is incredibly difficult reflecting her sense of guilt for abandoning her egalitarian values. Her guilt is exacerbated by her friends' commitment to the state school system despite their economic capability to afford a fee-paying school. Yet, Francesca is mindful of the cultural condition in which she is situated and in the context of a neoliberal society (Harvey, 2005), this necessitates putting her family first (Oría et al., 2007).

In sum, our analysis reveals the dynamics and conflicts experienced by middle-class parents as they consider the choice of schools for their children. Their experience suggests that the selection of school is often a classed practice, one that continues to widen social divisions and attainment gaps.

\section{Discussion}

This article sets out to understand the extent to which habituated class dispositions infiltrate parental choice within the British education marketplace. Specifically, we explore the way in which parents articulate their emotional and subjective experience of selecting a school for their children (Reay, 2005), through which vestiges of 'class talk' began to emerge. Our findings reveal three salient but interconnected patterns of 'class talk' - as participants express (1) class contempt to establish social distances from those 'not-like-them'; (2) a visceral sense of 'being-at-home/being estranged' within the schools they considered and (3) a sense of 'guilt' for going against their moral and political 'instincts'. These patterns of 'class talk' are enacted and indeed 'flow from' the 'sentient body' as participants' narration of school choice sensitises them to their habitus, enabling them to 'feel the game' (Bourdieu, 1990). As such our study reveals how the expressive order of class (Ball, 2003) subtly structures parental decision-making.

As our findings indicate, such decisions are far from rationally calculated; rather they are grounded in the 'embodied knowing' of class dispositions, infiltrated through their 'practical' and 'instinctive' engagement with the world. Most notably, our parental narratives reveal a deep-seated need to 'fit in', to 'feel at home' and indeed to 'be comfortable in the middle'. For these parents, the school constitutes a social space (Ball, 2003) that incites a visceral gut feeling (Bourdieu, 1990) which shapes their 'judgement' of cultural taste and social positions of those associated with the establishment. Belongingness is often experienced as a sense of 'familiarity' (Allen, 2002) - which parents such as Penny and Emma refer to as 'traditional' or 'good old fashioned' thus signifying a reverberation in class habituses where there is a seamless flow between 
the parents (and their children) and the school's body of population. For others, the experience of 'not being-at-home' is poignantly marked by disjuncture and alienation, suggesting a clashing/grating of habituses (Ball, 2003) that is analogous to a 'fish out of water' (Bourdieu, 1990).

For the majority of our participants, selecting a school that resonates with their habitus is paramount. Their choices speak not only to the aspiration for upward social mobility but also express the desire for their children to acquire the 'right' disposition and class taste (Byrne, 2009). This fuels the anxieties that their children may 'mix with the wrong crowd' (Ball, 2003). Their anxieties reflect bi-directional class contempt (Lawler, 2005a), as they imagine (1) the exclusion of their children by those 'superior' to them and (2) the contamination of class by the 'impoverished' other. This reinforces both inter as well as intra-class divisions, suggesting that school choice continues to reproduce class hierarchies through practices of social distancing (Atkinson, 2010).

Previous studies (e.g. Johnson, 2015; Reay \& Ball, 1997; Tyler, 2008) often indicate a downward symbolic violence (Atkinson, 2010) exercised by the privileged class (dominant group, often middle class) against those who are less privileged (dominated group, often working class). In a similar vein, our data found such downward symbolic violence being employed by our participants as an expression of inter-class conflict (e.g. Rebecca against 'children from bad background', Rachel and Louise being made to feel 'inferior') as well as intra-class conflict (Francesca [established wealth] against the 'nouveau riche'). Unlike previous studies however, our data also reveal an upward symbolic violence, which is often employed by our participants as an intra-class retaliation against the perceived antagonism (Tyler, 2008) directed at them by those within the 'middle strata', who proclaim superiority on the basis of excess wealth and academic competencies (e.g. Patricia, Brigit against the 'seriously wealthy', and Rachel against the 'privately educated'). Our findings therefore support Archer's (2011) call for a conceptualisation of the middle classes, not as a homogenous group, rather as a dynamic strata, characterised by internal divisions and nuanced distinctions. Interestingly, our participants are aware of the gradations of middle class hierarchy that segregate the 'elites' from the 'non-elites', the 'incredibly wealthy' from the 'working middle class', 'the established wealth' from 'the parvenus'. This suggests that the widening gap in 'social inequality' is beset as much by intra-class division as much as inter-class struggle. The choosing of school is therefore a micro-political act of class practice, one which reproduces social stratification facilitated by the market rules of exclusion (Ball, 2003).

We noted that while some parents confess to mobilising their market power to select schools that will ensure an advantageous 'head start' for their children (Bourdieu, 1986); others are aware of an inherent ideological conflict. These parents (e.g. Francesca, Emma, Stephanie) are conflicted by the competing desires to do the best for their own child while at the same time maintaining their egalitarian stance (Reay et al., 2008). For them, school choice is coalesced with an expressive order (Ball, 2003), from which the emotional tension of being a good parent and being a good citizen are played out. As market-citizens, parents are embroiled in a climate of choice that compels them to make 'responsible' decisions that prioritise their families (Oría et al., 2007), which at times goes against their moral and gut instincts. 
As such, school choice is orientated towards the preservation and inter-generational transmission of economic, social and cultural capitals (Bourdieu, 1986). Such hereditary distribution of capitals points to the enduring nature of habitus, which has led many to accuse Bourdieu of being deterministic (Reay, 2004a). In addition, Crossley (2001) argues that Bourdieu's lack of acknowledgement in the generative role of agency has rendered him vulnerable to the charge of determinism. However, Bourdieu and Wacquant (1992) dispute such an accusation, claiming that 'social agents are not particles that are mechanically pushed and pulled about by external forces' (p. 108), rather they argue that individuals actively exercise situated agency in relation to the social position they occupy and thus are able to transcend their habitus. As such, Hoy (1999) argues that despite its enduring character, habitus exhibits a degree of plasticity. This is most notable in the case of Louise who abandons her 'working class' habitus by opting into private education despite feeling 'out of place'. Meanwhile, Rachel, who despite being able to afford private education has gone against the grain of her middle class habitus by sending her child to a state school. Francesca has also noted the commitment of her bosom friends (doctor and his wife) to state education in support of a 'socialist' vision of an egalitarian society. However, as Reay et al.'s (2008, p. 252) study indicates such a decision 'stands out against normative white middle class practice'. They acknowledge the conflict and tension of leading an egalitarian lifestyle in a neoliberal individualistic society, as ensuring an advantageous 'head start' for their children (Bourdieu, 1986) is tantamount to being a good parent. Such a conflict is also experienced by Emma, who turns her back on state education despite her experience teaching in an inner-city comprehensive school. To some extent, this recognition of conflict counters criticisms that Bourdieu's concept of habitus is deterministic. While the middle class habitus fosters the ability to 'play the game' it also engenders the capacity for reflexivity (Atkinson, 2010), which points to a sense of class consciousness that supports a more egalitarian viewpoint. Crossley (2001) concurs stating that reflective choice is habitually rooted and thus routinely infiltrates everyday interaction in a manner that engenders embodied social agency. As such, habitus predisposes choice, without necessarily dictating choice (Reay, 2004a).

Yet, as Atkinson (2010) argues, while reflexivity is pivotal to inter-class movement and transcendence of one's habitus, it is nevertheless a privileged disposition open to those with cultural and economic capitals. As such, our data indicates that the ascension in social mobility (as demonstrated by Louise and Emma) has not erased class differences, rather it fortifies the dominance of the middle classes as the purchasing power of the upwardly mobile become incorporated by the 'upper' strata (Samuel, 1959) in a collective perpetuation of social inequality (Reay et al., 2008).

\section{Conclusion}

Through an exploration of 'class talk', our study advances understanding of the reproduction of class through language, by exploring how narratives of school choice articulate inter- and intra-class distinctions. In doing so, our research sheds light on the nuances and micro-political acts of status claiming, which are at once embodied and discursive. As such, our research contributes to the existing study of class in consumer research by addressing the expressive as well as relational dimensions of class 
distinctions and thus, reveals the plasticity of 'middle class' habitus, which is multilayered, enduring yet dynamic.

We demonstrate how social class as an embodied disposition continues to subtly influence choice. The subtleties in which class operates is in part attributed to the 'insidious' nature of 'class talk' in contemporary British society, in which overt reference to one's class (especially if one belongs to the upper strata of society) has become unacceptable. According to Young (2014), the increase in social inequality has created a 'vicious circle' in which the uneven distribution of wealth lies in opposition to the ideology of the supposedly 'classless society' - i.e. if we live in a classless society, as neoliberal policies maintain, then class inequality should disappear. The ideology of classlessness and social equality (as espoused by governmental policy) therefore drives the discourse of class underground, leaving 'class talk' a subtle practice. We therefore maintain that the influence of habitus and the class reflexivity it engenders in marketplace behaviour is under-represented because class has become an 'unspoken' topic.

We propose that consumer researchers, in exploring the socio-cultural workings of class, attend more closely to the discursive strategies of 'class talk' to reveal the concealed operations of social distinction. Future researchers should consider the gender division in class practices by exploring the cultivation of emotional capital and how emotional labour is differentially distributed across class structure (Reay, 2004c). Similarly, future studies of class should also attend to the experience of social inequality in the intersection of class and race (Johnson, 2015; Reay, 2008). As Harvey (2005, p. 202) noted, 'the lower classes are highly racialised and the increasing feminisation of poverty has been a notable feature of neoliberalism'.

In addition, our parental narratives highlight important policy implications. Throughout our findings evidence of the assumption of a neoliberal underpinning of market choice emerges: that market rules will lead to better schools for all and that individualism will encourage parents to take responsibility for making the best choices. We find little evidence that this works towards achieving social equality. Instead we suggest that choice, while a mirage for some, enables others to strive for the best for their child with little thought for the wider social good. Our findings reveal that the majority of our participants opted into the neoliberal ideology of self-advancement that is non-reflexive of class consciousness. However there is a small minority of participants who are disillusioned by the neoliberal promise of social mobility that induces an egalitarian political sentiment that points to their class consciousness. Yet even here, it takes a brave parent to prioritise the public good of an equal society over their own child's best interests.

More recently, the newly elected Conservative government has passed the Education and Adoption Bill (2015-16) mandating that under-performing schools be transformed into academies. ${ }^{8}$ However, Bedell (2008) cautions that academies risk exacerbating the 'privatisation of education' while simultaneously fostering an asymmetrical power that prioritises the vested interest of sponsors (which are usually made up of charities and businesses). Neil Kinnock, the former labour leader, expresses his concern over the creation of a 'seller market', where the school (under the influence of sponsors) dictates the type of students they are prepared to admit, thereby constituting a distortion of parental choice (BBC News, 2006). Kinnock's concern reflects Harvey's 
(2005) criticism of neoliberal policies, which serve only to restore the ruling power of free enterprises (sponsors). Meanwhile, the shifting of power from parents to academies/ sponsor potentially perpetuates social inequality in the educational system. To return to the start of this article, the closing of the attainment gap remains a utopian ideal yet to be achieved.

\section{Notes}

1. The latest report by Oxford University (2015) found that 'bright' children from deprived areas are half as likely to achieve three A 'Levels (35\%) compared to their better-off peers (60\%) since they are less likely to take or be offered 'facilitating' subjects (such as languages and sciences) that are crucial for securing a place at a good university (Weale, 2015).

2. According to Atkinson (2010, p. 69) the erosion of overt class differences are prompted by a series of political and cultural shifts, such as the decline in manufacturing, the weakening of trade unions, the democratisation of consumption, the postmodern blurring of high/low cultures and the increased access to education.

3. All children aged 5-16 are eligible for a free place at a state school in the UK. State school options include local community schools, faith schools, academies and grammar schools, which vary according to admissions criteria and extent of central government control. While pupils can apply to schools in other areas, oversubscribed schools may prioritise applications from pupils in the local geographic area (catchment area). Private schools, also known as independent or fee-paying schools, charge fees to attend (see www.gov.uk/ types-of-school/private-schools). Some older, more elite, prestigious fee-paying establishments are called public schools, although this is not the case in Scotland where the term refers to a state-run school.

4. According to Ball (2007) and Reay et al. (2008), the futures of middle-class offspring are progressively threatened by the downsizing of middle-management positions, breakdown of career security and the overproduction of professional graduates as a result of expansion in higher education.

5. Choice of secondary school was not the focus of this study as the child at age 11 plays an increasing role in the decision-making process of school selection, thereby obfuscating the exploration of parental choice.

6. Savage et al. (2013) propose a seven-tier British social class classification based on economic, social and cultural capitals: elite, established middle class, technical middle class, new affluent workers, traditional working class, emergent service workers and precariat.

7. Preparatory schools are fee-paying schools for children aged 8-13 set up to prepare children for their entry into public or independent schools.

8. Academies are state-funded schools that are backed by sponsors, first introduced to overcome the budgetary constraints and bureaucracy of local authorities by reallocating the funding and governance of schools to central government.

\section{Disclosure statement}

No potential conflict of interest was reported by the authors.

\section{Notes on contributors}

Beverley Hill is a Senior Lecturer in Marketing at Bristol Business School. Her research and teaching interests combine language and communication with critical marketing and consumer culture. Her research focuses on persuasion in public discourse, critiquing the influence of promotion on 
society, the pervasive spread of the language of the market and rhetorical function of organisational talk.

Ai-Ling Lai is a Lecturer in Marketing at the University of Leicester, School of Management. Her research focuses on hermeneutics and language, the body and consumer culture and the experience of singles in the marketplace. Her research has been published in the Journal of Marketing Management, Advances in Consumer Research, European Advances in Consumer Research and more recently in Death in Consumer Culture, a Routledge Interpretive Marketing Research series edited by Prof. Susan Dobscha.

\section{References}

Alexander, C. (2007). Forward. In D. Weekes-Bernard, School choice and ethnic segregation. The Runnymede Trust. Retrieved from http://www.runnymedetrust.org/uploads/publications/pdfs/ School\%20ChoiceFINAL.pdf

Allen, D. (2002). Toward a theory of consumer choice as sociohistorically shaped practical experience: The fits-like-a-glove (flag) framework. Journal of Consumer Research, 28(4), 515532. doi: $10.1086 / 338202$

Archer, L. (2011). Constructing minority ethnic middle class identity: An exploratory study with parents, pupils and young professionals. Sociology, 45(1), 134-151. doi:10.1177/ 0038038510387187

Archer, L., Hollingworth, S., \& Halsall, A. (2007). University's not for me - I'm a Nike Person': Urban, working-class young people's negotiations of 'style', identity and educational engagement. Sociology, 41(2), 219-237. doi:10.1177/0038038507074798

Argaman, E. (2009). Arguing within an institutional hierarchy: How argumentative talk and interlocutors' embodied practices preserve a superior-subordinate relationship. Discourse Studies, 11(5), 515-541. doi:10.1177/1461445609340498

Arnould, E., \& Thompson, C. (2005). Consumer culture theory (CCT): Twenty years of research. Journal of Consumer Research, 31(4), 868-882. doi:10.1086/426626

Arsel, Z., \& Bean, J. (2013). Taste regimes and market-mediated practice. Journal of Consumer Research, 39(5), 899-917. doi:10.1086/666595

Atkinson, W. (2010). Class, individualization and late modernity: In search of the reflexive worker. Basingstoke: Palgrave Macmillan.

Bagley, C., Woods, P., \& Glatter, R. (2001). Rejecting schools: Towards a fuller understanding of the process of parental choice. School Leadership \& Management, 21(3), 309-325. doi:10.1080/ 13632430120074455

Ball, S. (2003). Class strategies and the education market: The middle classes and social advantage. Falmer: Routledge.

Ball, S. (2007). Education plc: understanding private sector participation in public sector education. London: Routledge.

Ball, S. (2013). Education, justice and democracy: The struggle over ignorance and opportunity. London: Centre for Labour and Social Studies.

Bauman, Z. (1997). Postmodernity and its discontents. New York: New York University Press.

BBC News. (2006, April 18). Kinnock criticises city academies. BBC News Channel. Retrieved from http://news.bbc.co.uk/1/hi/uk_politics/4917808.stm

Bedell, G. (2008, August 31). Children of the revolution. The Guardian. Retrieved from http://www. theguardian.com/education/2008/aug/31/secondaryschools.schools

Bourdieu, P. (1977). Outline of a Theory of Practice. Cambridge: Cambridge University Press.

Bourdieu, P. (1984). Distinction: A social critique of the judgement of taste. (R. Nice Trans.). London: Routledge and Kegan Paul.

Bourdieu, P. (1986). The forms of capital. (R. Nice Trans.). In J. Richardson (Ed.), Handbook of theory of research for the sociology of education (pp. 241-258). New York: Greenwood Press.

Bourdieu, P. (1990). The logic of practice. Cambridge: Polity Press. 
Bourdieu, P., \& Wacquant, L. (1992). An invitation to reflexive sociology. Chicago, IL: The University of Chicago Press.

Brown, P. (2000). The globalisation of positional competition? Sociology, 34(4), 633-653. doi:10.1017/S0038038500000390

Byrne, B. (2009). Not just class: Towards an understanding of the whiteness of middle class schooling choice. Ethnic and Racial Studies, 32(3), 424-441. doi:10.1080/01419870802629948

Callaghan, G., \& Wistow, G. (2006). Publics, patients, citizens, consumers? Power and decision making in primary health care. Public Administration, 84(3), 583-601. doi:10.1111/j.14679299.2006.00603.x

Coskuner-Balli, G., \& Thompson, C. (2013). The status costs of subordinate cultural capital: At-home fathers' collective pursuit of cultural legitimacy through capitalizing consumption practices. Journal of Consumer Research, 40(1), 19-41. doi:10.1086/668640

Crossley, N. (2001). The phenomenological habitus and its construction. Theory and Society, 30(1), 81-120. doi:10.1023/A:1011070710987

David, M., West, A., \& Ribbens, J. (1994). Mothers intuition? Choosing secondary schools. London: The Falmer Press.

Deputy Prime Minister's Office. (2015, March 25). Social Mobility Indicators. Retrieved from https:// www.gov.uk/government/publications/social-mobility-indicators/social-mobility-indicators

Education and Adoption Bill (2015-16). Department of Education, Retrieved from http://services. parliament.uk/bills/2015-16/educationandadoption.html (Accessed 20 November 2015).

Fish, S. (1980). Is there a text in this class? The authority of interpretive communities. Cambridge: Harvard University Press.

Frean, A. (2008, October 11). Comprehensives 'more exclusive than grammars': Parents' school selection adds to social division. The Times.

Gewirtz, S., Ball, S., \& Bowe, R. (1992, August 31). Parents, privilege and the educational marketplace. Paper presented at the British Educational Research Association Annual Conference. Stirling University, Stirling.

Gov.UK. (2014). Schools, pupils and their characteristics. Retrieved from https://www.gov.uk/gov ernment/publications/schools-pupils-and-their-characteristics-january-2014 (Accessed 5 February 2015)

Hall, S. (1958). A sense of classlessness. Universities \& Left Review, 5(Autumn), 26-32. Retrieved from http://amielandmelburn.org.uk/collections/ulr/05_26.pdf

Harvey, D. (2005). A brief history of neoliberalism. Oxford : Oxford University Press.

Hayward, K., \& Yar, M. (2006). The 'Chav' phenomenon: Consumption, media and the construction of a new underclass. Crime, Media and Culture, 2(1), 9-28. doi:10.1177/1741659006061708

Heath, N. (2009). Veiled and overt school choice: A consideration of the ways in which different forms of school choice affect student experiences. British Educational Research Journal, 35(4), 539-555. doi:10.1080/01411920802044479

Henry, P. (2005). Social class, market situation and consumers' metaphors of (dis)empowerment. Journal of Consumer Research, 31(4), 766-778. doi:10.1086/426610

Henry, P., \& Caldwell, M. (2008). Spinning the proverbial wheel? Social class and marketing. Marketing Theory, 8(4), 387-405. doi:10.1177/1470593108096542

Holt, D. (1998). Does cultural capital structure American consumption? In J. Schor, \& D. Holt (Eds.), The consumer society reader (pp. 212-252). New York, NY: The New York Press.

Hoy, D. (1999). Critical resistance: Foucault and Bourdieu. In H. Haber, \& G. D. Weiss (Eds.), Perspectives on embodiment: The intersections of nature and culture (pp. 3-22). London: Routledge.

Huggins, M. (2008). Sport and the British upper classes c.1500-2000: A historiographic overview. Sport in History, 28(3), 364-388. doi:10.1080/17460260802315470

ISC (Independent Schools Council). (2013). Annual Census. Retrieved from http://www.isc.co.uk/ research/Publications/annual-census/isc-annual-census-2013

Johnson, H. B. (2015). The American dream and the power of wealth: Choosing schools and inheriting inequality in the land of opportunity. New York, NY: Routledge. 
Johnston, J., \& Baumann, S. (2007). Democracy versus distinction: A study of omnivorousness in gourmet food writing. American Journal of Sociology, 113(1), 165-204. doi:10.1086/518923

Johnston, J., Szabo, M., \& Rodney, A. (2011). Good food, good people: Understanding the cultural repertoire of ethical eating. Journal of Consumer Culture, 11(3), 293-318. doi:10.1177/ 1469540511417996

Kravets, O., \& Sandikci, O. (2014). Competently ordinary: New middle class consumers in the emerging markets. Journal of Marketing, 78(4), 125-140. doi:10.1509/jm.12.0190

Lawler, S. (2005a). Disgusted subjects: The making of middle class identities. The Sociological Review, 53(3), 429-446. doi:10.1111/j.1467-954X.2005.00560.x

Lawler, S. (2005b). Introduction: Class, culture and identity. Sociology, 39(5), 797-806. doi:10.1177/ 0038038505058365

Lucey, H., \& Reay, D. (2002). Carrying the beacon of excellence: Social class differentiation and anxiety at a time of transition. Journal of Education Policy, 17(3), 321-336. doi:10.1080/ 02680930210127586

Mishler, E. (1986). The analysis of interview narratives. In T. Sarbin (Ed.), Narrative psychology: The storied nature of human conduct. Westport, CT: Preager.

ONS. (2011). Census gives insights into characteristics of the south west's population, Office for National Statistics. Retrieved from http://www.ons.gov.uk/ons/dcp29904_291548.pdf (Accessed 20 October 2015)

Oría, A., Cardini, A., Ball, S., Stamou, E., Kolokitha, M., Vertigan, S., \& Flores-Moreno, C. (2007). Urban education, the middle classes and their dilemmas of school choice. Journal of Education Policy, 22(1), 91-105. doi:10.1080/02680930601065791

Perrier, M. (2012). Middle-class mothers' moralities and 'concerted cultivation': Class others, ambivalence and excess. Sociology, 47(4), 655-670. doi:10.1177/0038038512453789

Perry, E., \& Francis, B. (2010). The social class gap for educational achievement: A review of the literature (RSA Projects). Retrieved from http://www.thersa.org/action-research-centre/learning,cognition-and-creativity/education/social-justice/the-social-class-gap-for-educational-achieve ment-a-review-of-the-literature

Polanyi, K. (1944). The great transformation: The political and economic origins of our time. Boston: Beacon Press.

Rademacher, M. (2008). Fashion and the college transition: Liminality, play, and the structuring power of the habitus. In A. Y. Lee, \& D. Soman (Eds.), Advances in Consumer Research (pp. 393400). Duluth, MN: Association for Consumer Research.

Rafferty, K. (2011). Class-based emotions and the allure of fashion consumption. Journal of Consumer Culture, 11(2), 239-260. doi:10.1177/1469540511403398

Reay, D. (2004a). It's all becoming a habitus: Beyond the habitual use of habitus in educational research. British Journal of Sociology of Education, 25(4), 431-444. doi:10.1080/ 0142569042000236934

Reay, D. (2004b). 'Mostly roughs and toughs': Social class, race and representation in inner city schooling. Sociology, 38(5), 1005-1023. doi:10.1177/0038038504047183

Reay, D. (2004c). Gendering Bourdieu's concept of capitals? Emotional capital, women and social class. The Sociological Review, 52, 57-74. doi:10.1111/j.1467-954X.2005.00524.x

Reay, D. (2005). Beyond consciousness? The psychic landscape of social class. Sociology, 39(5), $911-$ 928. doi:10.1177/0038038505058372

Reay, D. (2006). The zombie stalking english schools: social class and educational inequality. British Journal of Educational Studies, 54(3), 288-307. doi:10.1111/j.1467-8527.2006.00351.x

Reay, D. (2008). Psychosocial aspects of white middle-class identities: Desiring and defending against the class and ethnic 'other' in urban multi-ethnic schooling. Sociology, 42(6), 1072-1088. doi:10.1177/0038038508096934

Reay, D., \& Ball, S. (1997). 'Spoilt for Choice': The working classes and education markets. Oxford Review of Education, 23(1), 89-101. doi:10.1080/0305498970230108

Reay, D., Crozier, G., James, D., Hollingworth, S., Williams, K., Jamieson, F., \& Beedell, P. (2008). Reinvigorating democracy? White middle class identities and comprehensive schooling. The Sociological Review, 56(2), 238-255. doi:10.1111/j.1467-954X.2008.00786.x 
Riessman, C. K. (2004). Narrative analysis. In M. S. Lewis-Beck, A. Bryman, \& T. Futing Liao (Eds.), The Sage encyclopedia of social science research methods (Vol. 3). Thousand Oaks, CA: Sage.

Rivera, L. (2015). Pedigree: How elite students get elite jobs. Princeton, NJ: Princeton University Press. Rose, N. (1992). governing the enterprising self. In P. Heelas, \& P. Morris (Eds.), The values of the enterprise culture: The moral debate. London: Routledge.

Samuel, R. (1959). Class and classlessness. Universities \& Left Review, 6(Spring), 44-49. Retrieved from http://www.amielandmelburn.org.uk/collections/ulr/06_44.pdf

Savage, M. (2000). Class analysis and social transformation. Buckingham: Open University Press.

Savage, M., Devine, F., Cunningham, N., Taylor, M., Li, Y., Hjellbrekke, J., ... Miles, A. (2013). A new model of social class: Findings from the BBC's Great British Class Survey Experiment. Sociology, 0 (0), 1-32. doi:10.1177/0038038513481128

Sayer, A. (2002). What are you worth?: Why class is an embarrassing subject. Sociological Research Online, 7, 3. Retrieved from http://www.socresonline.org.uk/7/3/sayer.html

Shepherd, J. (2010, July 28). Rich, thick kids' achieve much more than poor clever ones, says Gove. The Guardian. Retrieved from: http://www.theguardian.com/education/2010/jul/28/gove-acade mies-rich-thick-kids

Thompson, C., \& Haytko, D. (1997). Speaking of fashion: Consumers' uses of fashion discourses and the appropriation of countervailing cultural meanings. Journal of Consumer Research, 24(1), 1542. doi:10.1086/209491

Tyler, I. (2008). Chav mum chav scum: Class disgust in contemporary Britain. Feminist Media Studies, 8(1), 17-34. doi:10.1080/14680770701824779

Üstüner, T., \& Holt, D. (2010). Toward a theory of status consumption in less industrialized countries. Journal of Consumer Research, 37(1), 37-56. doi:10.1086/649759

Veblen, T. (1899). Theory of the leisure class: An economic study in the evolution of institutions. New York, NY: Macmillan.

Weale, S. (2015, March 17). Bright pupils more likely to fall behind if from poor background, study finds. The Guardian. Retrieved from http://www.theguardian.com/education/2015/mar/17/poorbright-pupils-aged-11-fall-behind-by-a-levels-study-finds

Weber, M. (1905/2012). The protestant ethic and the spirit of capitalism. United States: Renaissance Classics.

Weekes-Bernard, D. (2007). School choice and ethnic segregation. London: The Runnymede Trust. Retrieved from http://www.runnymedetrust.org/uploads/publications/pdfs/School\% 20ChoiceFINAL.pdf

Wengraf, T. (2001). Qualitative research interviewing: Biographic narrative and semi-structured methods. London: Sage Publications.

Young, T. (2014, January 25). Britain's upper class is how too snobbish to speak its name. The Spectator. Retrieved from http://www.spectator.co.uk/life/status-anxiety/9121471/the-classthats-too-snobbish-to-speak-its-name/ 


\section{Appendix A: Profile of participants}

\begin{tabular}{|c|c|c|c|}
\hline Participant pseudonym & Occupation & Types of school considered & Type of school chosen \\
\hline Angela & Teacher (State school) & Fee paying and state & State \\
\hline Bea & Not revealed & State & State \\
\hline Brigit & Solicitor & Fee paying and state & Fee paying \\
\hline Diane & Full time mother & State & State \\
\hline Emily & Nurse & State & State \\
\hline Emma & Teacher (State school) & Fee paying and state & Fee paying \\
\hline Esther & Not revealed & State & State \\
\hline Felicity & Documentary film maker & Fee paying and state & Fee paying \\
\hline Francesca & Artist & Fee paying and state & Fee paying \\
\hline Iris & Not revealed & State & State \\
\hline Jayne & Teacher (State school) & State & State \\
\hline Jeanette & Administrator & State & State \\
\hline Jenny & Full time mother & State & State \\
\hline Jilly & Health visitor & State & State \\
\hline Joanna & Teacher (Fee-paying school) & Fee paying and state & State \\
\hline Kate & Mature student & State & State \\
\hline Katie & School worker & State & State \\
\hline Liz & Full time mother & State & State \\
\hline Louise & Social worker & Fee paying and state & Fee paying \\
\hline Lydia & Works in architect practice & Fee paying and state & Fee paying \\
\hline Mandy & Administrator & State & State \\
\hline Margot & Full time mother & State & State \\
\hline Patricia & Physiotherapist & Fee paying and state & Fee paying \\
\hline Penny & Teacher (State school) & Fee paying and state & Fee paying \\
\hline Rachel & Manager & Fee paying and state & State \\
\hline Rebecca & Teacher (State school) & State & State \\
\hline Rose & In training & State & State \\
\hline Stella & Not revealed & Fee paying and state & State \\
\hline Stephanie & Lecturer & Fee paying and state & Fee paying \\
\hline Suzanna & Full time mother & State & State \\
\hline
\end{tabular}

